\title{
ADEQUACY OF THE AMOUNT OF OWN RESOURCES OF FOOD ACCOUNTING ENTITIES IN 2018 IN SLOVAKIA
}

\author{
Katarína Tasáryová ${ }^{1}$ \\ Renáta Pakšiová ${ }^{2}$
}

DOI: https://doi.org/10.31410/ITEMA.2019.85

\begin{abstract}
It is very important for these companies to choose an adequate asset resource structure in order to eliminate risks in their business. It includes, for example, the risks associated with reduced solvency due to high indebtedness, thus the high value of external assets and low liquidity of assets. On the other hand, the high level of own resources of assets is not an unambiguously positive indicator, as own resources of assets are objectively one of the most expensive. Establishing an adequate level of own resources of assets in company is a key role of management in its optimal business setup towards long-term positive business results. The aim of the paper is to assess the adequacy of the amount of own resources of food business in 2018 in Slovakia on the basis of financial analysis indicators.
\end{abstract}

Keywords: Equity, Capital, Non-Current Assets Long-Term Liabilities, Golden Rule of Financing

\section{INTRODUCTION}

$\mathrm{T}$ oday, companies are becoming increasingly demanding in terms of competition. There is a constant increase in the number of companies aiming to achieve the best possible market position. It is important for these companies not only to make profits and reduce costs, but also to optimally set up the resources to finance their respective types of assets, given the obvious advantages and disadvantages of each. Therefore, business entities have to look for an answer to the question of how they will finance their assets. Optimizing the resources of property finance is a very demanding and time-consuming process for which the company is making a lot of effort. Property resources can be explored from two perspectives. The first aspect deals with the origin of assets, the subject of which is the perspective of the company, which is the basis of the division of resources into own and foreign. Own resources represent the contributions of the owners and foreign liabilities are associated with the obligation to return these resources to the creditor within a specified time. Second, the legal aspect refers to claims of third subjects against the company, which have a dual nature (Šlosárová, 2018):

- legal claims of various creditors of the company, such as employees, suppliers, state, banks, and so on,

- legal claims of owners to the assets of the company.

The assessment of the adequacy of the amount of own resources of company property is important for several reasons. To assess the adequacy of the amount of own resources it is possible to use the golden rule of financing, where the sum of non-current assets should correspond to the amount of own resources and long-term liabilities. The adequacy of own resources means not only that the company can finance its business mainly through its own resources, but also that it is creditworthy in the eyes of its business partners. It will also avoid liquidity problems. In

University of Economics in Bratislava, Dolnozemská cesta 1, 85235 Bratislava, Slovakia

University of Economics in Bratislava, Dolnozemská cesta 1, 85235 Bratislava, Slovakia 
cases where short-term foreign (recoverable) resources are at most equal to current (short-term) assets, it is more likely to be able to settle its liabilities on time.

When examining food companies operating in Slovakia in 2018, it is necessary to analyze data from the individual financial statements of these companies. The financial statements are available on the publicly available state-managed website of the register of financial statements (http://www.registeruz.sk) or the private company Finstat (https://www.finstat.sk). The authors included all companies with the scope of SK NACE from 10110 to 11070 in the research. From the published financial statements of individual companies for the year 2018 the balance sheet containing the items of assets and liabilities of examined companies is relevant for authors research. The following items are selected from the items of assets and liabilities: non-current assets, equity and long-term liabilities. Based on the data sets obtained for the whole group of food industry companies in the Slovak Republic, the authors analyzed the fulfillment of the requirements of the golden rule of financing for 2018. Visualization of the results of the research is presented in the form of tables and graphs.

\section{THEORETICAL BASIS FOR THE ASSESSMENT OF THE ADEQUACY OF THE AMOUNT OF THE OWN RESOURCES OF COMPANIES}

Financing through own resources is often more expensive than financing through external resources. The way, form and technique of own funds financing depends, firstly, on the choice of the legal form of business and, secondly, on the size and procedure of collecting the owners' deposits according to the size of the company (Šebo, 2014). The company's own resources are cumulated as owners' deposits and the components produced from the company's profits during its existence and represent long-term resources of financing.

In the case of optimum financing of assets, it is necessary to respect, among other things, the golden rule of financing, which expresses the coherence between the availability of financial resources and the tying of assets acquired through them. Pursuant to that rule, the resources by which the various components of assets are financed should be available in the undertaking for at least the period during which the relevant component of assets is committed in the undertaking.

Own resources are a permanent resource, which is always available to the company. In accounting, own resources are defined as equity, which is generally described in the Accounting Act as a difference between assets and liabilities. In $\S 2$ par. article 2 of the Accounting Act (2019) states: "The accounting is to account for facts about the state and movement of assets, the state and movement of liabilities, the difference between assets and liabilities, income, expenses, takings, outgoings and profit or loss". The definition of the difference between assets and liabilities is dealt with in the accounting procedures for entrepreneurs ${ }^{3}$ in $\S 59$ par. 1, where it is determined that equity is the difference between assets and liabilities. The difference in assets and liabilities is an indirect definition of equity based on a modified extended balance sheet equation having the form:

$$
\text { Equity }=\text { Assets }- \text { Liabilities }
$$

Decree of the Ministry of Finance of the Slovak Republic no. 23054/2002-92 laying down details of accounting procedures and framework chart of accounts for entrepreneurs accounting in the double entry bookkeeping system, as amended (hereinafter referred to as "accounting procedures"). 
The accounting procedures for double-entry bookkeeping entrepreneurs list the equity components with the appropriate numerical and verbal representation of the framework chart of accounts for entrepreneurs where specific equity components are accounted for (Table 1).

Table 1. Numerical and verbal indication of equity account

\begin{tabular}{|c|l|}
\hline Number of account & Name of account \\
\hline 411 & Capital \\
\hline 412 & Share premium \\
\hline 413 & Other capital funds \\
\hline 414 & Valuation differences from the revaluation of assets and liabilities \\
\hline 416 & Valuation differences from revaluation in mergers, fusions and divisions \\
\hline 417 & Legal reserve fund from capital contributions \\
\hline 418 & Indivisible fund from capital contributions \\
\hline 419 & Changes in capital \\
\hline 421 & Legal reserve fund \\
\hline 427 & Other funds \\
\hline 428 & Retained earnings from previous years \\
\hline 429 & Accumulated losses from previous years \\
\hline 431 & Economic result of approval \\
\hline
\end{tabular}

Source: Decree of the Ministry of Finance of the Slovak Republic no. 23054/2002-92 laying down details of accounting procedures and framework chart of accounts for entrepreneurs in the double entry accounting system, as amended

The Commercial Code characterizes net business assets, which are "business assets after deduction of obligations incurred by the entrepreneur in connection with the business" (Commercial Code, $\S 6$ paragraph 3). Equity is formed by own resources of financing business assets of the entrepreneur according to a special regulation (Commercial Code $\S 6$, paragraph 4). In simplified terms, equity can be said to be an accounting expression of net assets or, conversely, net assets expressed in accounting are called equity. Since part of the business assets do not meet the definition of assets under the Accounting Act and part of the liabilities under the Commercial Code do not meet the definition of liabilities under the Accounting Act, part of the business capital cannot be considered part of equity, which means that this part is not recognized in the balance sheet (Farkaš, 2018).

The most important component of equity is the capital, which represents the monetary expression of the sum of monetary and non-monetary contributions of all partners to the company (Commercial Code $\S 58$, paragraph 1). The capital is compulsorily created by limited liability companies of at least $€ 5,000$, joint stock companies of at least $€ 25,000$ and simple companies for shares of at least $€ 1$. In the case of cooperatives, the capital is made up of the sum of the membership deposits on which the individual members of the cooperative undertake to repay and whose minimum amount is equivalent to $€ 1250$. Limited partnerships are not legally obliged to create registered capital, but the Commercial Code provides for a minimum deposit of limited partners in the amount of $250 €$ (Srnišová, 2018).

\section{ANALYSIS OF FOOD COMPANIES IN SLOVAKIA IN 2018}

Pursuant to the legislation of the Slovak Republic, companies accounting in the double entry bookkeeping system report equity in the balance sheet. The balance sheet is one of the components of the financial statements (Šlosárová, 2017). Companies are required by the Accounting Act to deposit the financial statements in the register of financial statements, which is publicly 
available on the website http://www.registeruz.sk. Financial statements and information on individual companies as well as financial results are also provided by the private company Finstat. In both sources, data is generated in the form of table to a limited extent. To obtain more extensive and detailed data, it is necessary to add data from individual financial statements that are relevant to author's research. These data include, for example, equity, long-term liabilities and so on.

The subject of the research are food companies established in the Slovak Republic. In 2018, there are 2,045. In accordance with the golden rule of financing, the resources used to finance assets should be available at least for the period during which the assets in question are tied to the company. It follows from the foregoing, that when examining golden rule of financing, all long-term resources can be included in the research, that is to say, in addition to equity, longterm liabilities, because these are available in company for more than 1 year. Long-term liabilities include the following items: long-term trade payables, other long-term payables and longterm bank loans. From the food companies examined in 2018, $20.83 \%$ of companies are able to finance their assets through their own resources, $44.84 \%$ of companies do not meet the golden rule of financing, so long-term resources are not sufficient to finance assets. For the remaining undertakings, compliance with the golden financing rule cannot be determined because they do not recognize non-current assets or equity. $6.65 \%$ of the examined food companies need longterm liabilities in addition to equity to finance non-current assets (Graph 1).

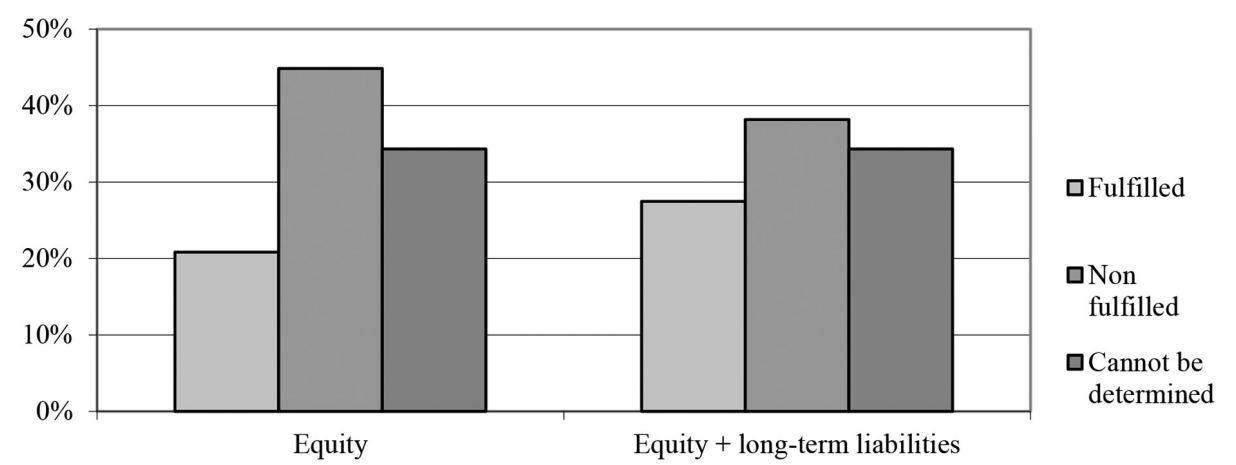

Graph 1. Assessment of Compliance with the Golden Funding Rule

Source: Own calculations based on company's financial statements

The examined companies have a different legal form of business, with the most represented limited liability companies and the least state-owned enterprises. The authors focused on meeting the golden rule of financing and also on the reported equity. From the balance sheet of individual companies, three items are relevant for the author's research, namely equity, non-current assets and long-term liabilities. The golden rule of financing is fulfilled, if the value of equity and long-term liabilities is equal to or higher than the value of non-current assets. From the point of view of the analysis of the group of companies, that meet the golden rule of financing according to their legal forms, the most are limited partnership (90.60\%), followed by joint stock companies $(7.68 \%)$ and the remainder being limited partnerships and cooperatives. From the examined companies state-owned enterprises and simple companies for shares do not meet the golden rule of financing (Table 2). This structure was expected due to the uneven distribution of the number of companies by legal form of business. 
Table 2: Structure of companies according to the legal form of business and meeting the golden rule of financing in each legal form of business

\begin{tabular}{|l|c|c|l|c|}
\hline $\begin{array}{l}\text { Legal form of } \\
\text { business }\end{array}$ & $\begin{array}{l}\text { Total number of } \\
\text { companies in legal } \\
\text { form of business }\end{array}$ & $\begin{array}{l}\text { Number of companies } \\
\text { meeting the golden } \\
\text { rule of financing }\end{array}$ & $\begin{array}{l}\text { Share of companies } \\
\text { in legal form of } \\
\text { business meeting } \\
\text { the golden rule of } \\
\text { financing (in \%) }\end{array}$ & $\begin{array}{l}\text { Share of legal form of } \\
\text { business on meeting } \\
\text { the golden rule of } \\
\text { financing (in \%) }\end{array}$ \\
\hline General partnership & 8 & 3 & 37.50 & 0.58 \\
\hline $\begin{array}{l}\text { State-owned } \\
\text { company }\end{array}$ & 1 & - & - & - \\
\hline $\begin{array}{l}\text { Limited liability } \\
\text { company }\end{array}$ & 1912 & 472 & 24.69 & 90.60 \\
\hline Limited partnership & 6 & 1 & 16.67 & 0.18 \\
\hline $\begin{array}{l}\text { Simple company for } \\
\text { shares }\end{array}$ & 2 & - & - & - \\
\hline Cooperative & 13 & 5 & 38.46 & 0.96 \\
\hline Joint stock company & 103 & 40 & 38.83 & 7.68 \\
\hline Total & 2045 & 521 & - & 100 \\
\hline
\end{tabular}

Source: Own calculations based on company's financial statement

According that one of the relevant items in the assessment of the golden rule of financing is equity, it is necessary to assess its amount in terms of legal forms of business. Limited liability companies, joint stock companies, simple companies for shares, limited partnerships and cooperatives have a prescribed amount of equity or minimum deposit, so these companies should not report zero or negative equity, because this would mean for a particular company, that it does not have enough own resources to cover the assets, which means the property is covered by foreign resources (liabilities). Also, company would have to convert assets into cash as soon as possible to ensure liquidity. From the examined companies, limited liability companies have the highest representation, of which $73.22 \%$ recognize a positive equity (Table 3 ).

Table 3: Structure of equity in individual legal forms of business

\begin{tabular}{|l|c|c|l|l|l|}
\hline $\begin{array}{l}\text { Legal form of } \\
\text { business }\end{array}$ & $\begin{array}{l}\text { Total number } \\
\text { of companies } \\
\text { in legal form of } \\
\text { business }\end{array}$ & $\begin{array}{l}\text { Share of } \\
\text { companies in legal } \\
\text { form of business } \\
\text { with positive } \\
\text { equity (in \%) }\end{array}$ & $\begin{array}{l}\text { Share of } \\
\text { companies in legal } \\
\text { form of business } \\
\text { with negative } \\
\text { equity (in \%) }\end{array}$ & $\begin{array}{l}\text { Share of } \\
\text { companies in } \\
\text { legal form of } \\
\text { business with no } \\
\text { equity (in \%) }\end{array}$ & Total (in \%) \\
\hline $\begin{array}{l}\text { General } \\
\text { partnership }\end{array}$ & 8 & 100 & - & - & 100 \\
\hline $\begin{array}{l}\text { State-owned } \\
\text { company }\end{array}$ & 1 & 100 & - & 1.62 & 100 \\
\hline $\begin{array}{l}\text { Limited liability } \\
\text { company }\end{array}$ & 1912 & 73.22 & 25.16 & - & 100 \\
\hline $\begin{array}{l}\text { Limited } \\
\text { partnership }\end{array}$ & 6 & 66.67 & 33.33 & - & 100 \\
\hline $\begin{array}{l}\text { Simple company } \\
\text { for shares }\end{array}$ & 2 & 50.00 & 50.00 & - & 100 \\
\hline Cooperative & 13 & 84.62 & 15.38 & & 100 \\
\hline $\begin{array}{l}\text { Joint stock } \\
\text { company }\end{array}$ & 103 & 90.29 & 8.7 & 0.97 & \\
\hline
\end{tabular}

Source: Own calculations based on company's financial statement

The examined food companies are represented in all regional territorial units of Slovakia, with the Banská Bystrica region ranking first and the Bratislava region ranking last (Figure 1). 


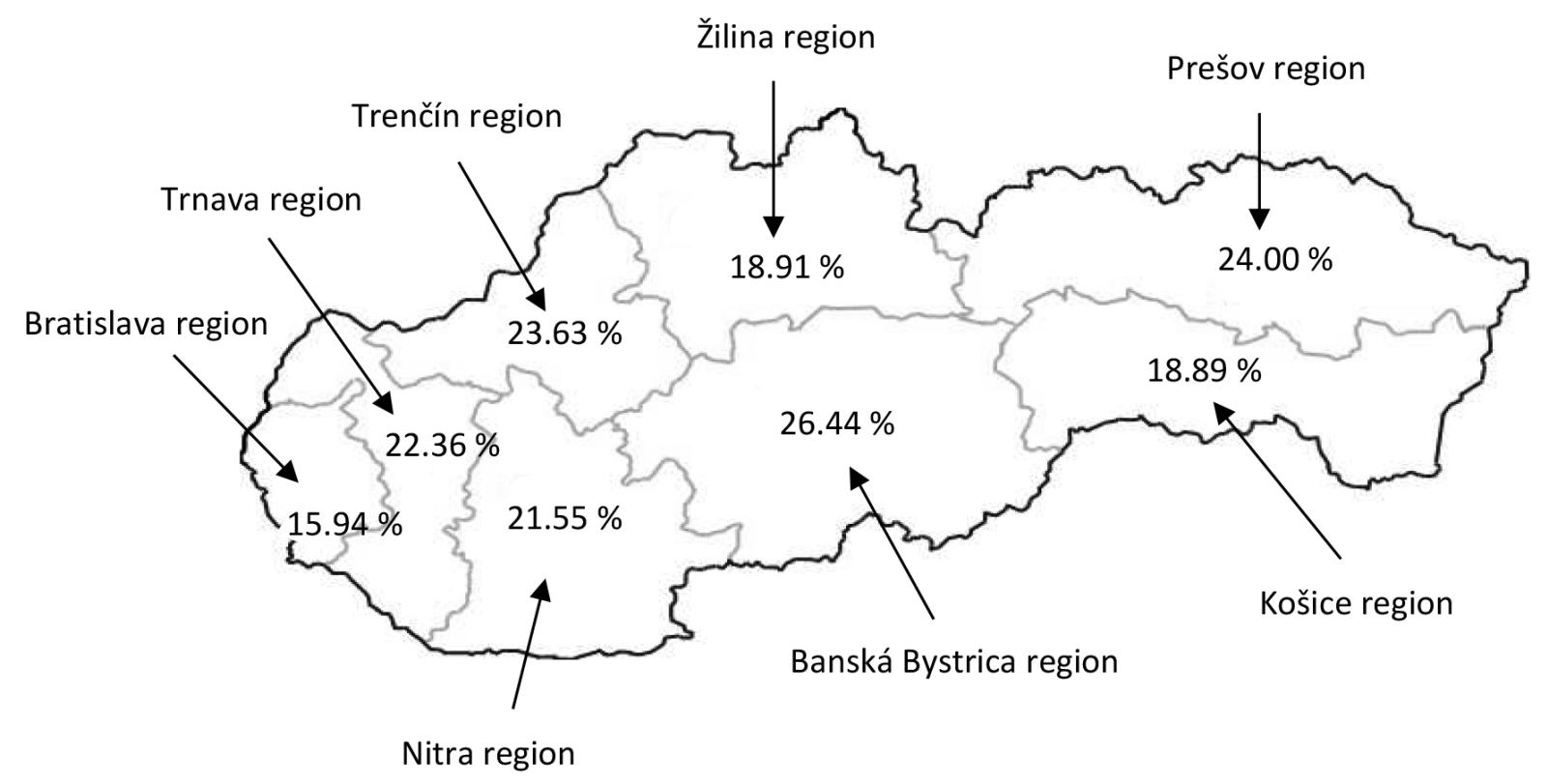

Figure 1: Assessment of the golden rule of financing in individual regions in Slovakia

Source: Own calculations based on company's financial statement

\section{FUTURE RESEARCH DIRECTIONS}

The future research will focus on the assessment of the structure of equity and the dependence of the amount of equity and specific types of assets, as well as efforts to identify direct sources of financing of the acquired fixed assets. It will also analyze the distribution of profit and the settlement of losses in companies in relation to their consequences in business performance and profitability in subsequent accounting periods. The causes of the established reporting of zero or negative equity of some companies in 2018 will also be analyzed. The observed differences in the fulfillment of the golden rule of financing in relation to the national economic parameters of the territorial units of Slovakia will be further analyzed.

\section{CONCLUSION}

Own resources represent a permanent resource for a company that exists in the company throughout the business. These are long-term resources that are constantly available in the company, so they should be tied especially to non-current assets, that are used by a particular company in the long term. In accounting, equity is understood as equity, which is the difference between the entity's assets and liabilities. At the inception of the company, equity consists of deposits that individual partners invested in the company (Máziková, 2016). During the conduct of business activity is created from internal or external resources. Internal resources are resources created by the company's own operations, from the profit. External resources are obtained from external environment, respectively they arise from changes in the company's external environment, such as donations received from partners or positive valuation differences from the revaluation of assets. The most important component of the equity of companies is the capital representing the monetary expression of the sum of monetary and non-monetary contributions of all partners in the company.

Research has shown that only $20.83 \%$ of food companies meet the golden rule of financing in the Slovak Republic in 2018, which means that they have enough own resources to cover 
non-current assets. Taking into account the long-term liabilities available to businesses for more than one year, the results increased by only $6.65 \%$. At $34.33 \%$ of food companies, compliance with the golden rule of financing cannot be determined, because they do not show one of the necessary items for research, equity, non-current assets or long-term liabilities. The remaining companies do not have enough own resources and long-term liabilities to finance non-current assets, which means that non-current assets are also covered by short-term liabilities, which may cause the company's solvency and liquidity problems.

When analyzing the amount of equity, the most attention is given to limited liability companies, as they have the highest representation in the examined food companies. In these companies, the value of the capital should be at least $€ 5000$, which means that the value of the equity in these companies should not be zero or negative. Research shows that $92.41 \%$ of limited liability companies report positive equity. Zero, respectively the negative equity of companies indicates that their liabilities are equal, respectively higher than their assets. This situation is negative not only for company's owners, but also for creditors. If this situation arises, companies should try to increase the value of equity as soon as possible so that its total amount reaches positive value.

According to the individual regions of the Slovak Republic, the Banská Bystrica Region is the first in terms of compliance with the golden rule of financing, where $26.44 \%$ of food companies have enough own resources to cover non-current assets. The last place is the Bratislava Region, where only $15.94 \%$ of companies meet the golden rule of financing.

The total research shows that in 2018, approximately one quarter of food companies in Slovakia meet the golden rule of financing, which is a very low percentage. The majority of companies should seek to increase equity so that they are able to finance their business mainly from their own resources while increasing credibility with creditors.

\section{ACKNOWLEDGMENT}

This article is an output of the project APVV no. APVV-16-0602 "Enhancement of the relevance of the accounting data in the SR - from expenses to value".

\section{REFERENCES}

Farkaš, R. (2018). Vlastné imanie obchodných spoločností. Účtovné aspekty. Bratislava: Wolters Kluwer.

Máziková, K., Ondrušová, L. \& Seneši, N. (2016). Účtovníctvo vlastníckych transakcií. Bratislava: Wolters Kluwer.

Opatrenie MF SR č. MF/23054/2002-92, ktorým sa ustanovujú podrobnosti o postupoch účtovania a rámcovej účtovej osnove pre podnikatel'ov účtujúcich $\mathrm{v}$ sústave podvojného účtovníctva v znení neskorších predpisov.

Srnišová, P. (2018). Záporné vlastné imanie ako indikátor existencie transakcií medzi spriaznenými osobami: Negative Equity as an Indicator of the Existence of Transactions Between Related Parties. MMK 2018: recenzovaný sborník př́spěvkì z mezinárodní Masarykovy konference pro doktorandy a mladé vědecké pracovníky, ročník IX., 17. - 21. prosince 2018, Hradec Králové, Česká republika. (pp. 381-386). Hradec Králové: MAGNANIMITAS.

Šebo, A. (2014). Podnikov financie. Nitra: Vydavatel'stvo SPU. 
Šlosárová, A. (2018). Zmeny vo vykazovaní položiek vlastného imania v súvahe podnikatela a ich vplyv na finančnú situáciu účtovnej jednotky: Changes in presenting of equity items in balance sheet of entrepreneur and their impact on financial position of accounting entity. AIESA - budovanie spoločnosti založenej na vedomostiach: zborník: 16. medzinárodná vedecká konferencia: Bratislava, 5. - 6. november 2015. (pp. 376-386). Bratislava: Vydavatel'stvo EKONÓM.

Šlosárová, A., Blahušiaková, M. (2017). Analýza účtovnej závierky. Bratislava: Wolters Kluwer. Zákon č. 431/2002 Z. z. o účtovníctve v znení neskorších predpisov.

Zákon č. 513/1991 Zb. Obchodný zákonník v znení neskorších predpisov. 